OPEN ACCESS

Edited by:

Lino Nobili,

University of Genova, Italy

Reviewed by:

Satvinder Kaur,

Beth Israel Deaconess Medical

Center, Harvard Medical School,

United States

Viliam Donic,

University of Pavol Jozef Šafárik,

Slovakia

*Correspondence:

Irma Rukhadze

irukhadze@ucla.edu

Specialty section

This article was submitted to

Sleep and Chronobiology,

a section of the journal

Frontiers in Neurology

Received: 19 June 2018

Accepted: 20 August 2018

Published: 10 September 2018

Citation:

Rukhadze I and Fenik VB (2018)

Neuroanatomical Basis of

State-Dependent Activity of Upper

Airway Muscles. Front. Neurol. 9:752.

doi: 10.3389/fneur.2018.00752

\section{Neuroanatomical Basis of State-Dependent Activity of Upper Airway Muscles}

\author{
Irma Rukhadze ${ }^{1,2 *}$ and Victor B. Fenik ${ }^{1,3}$ \\ ${ }^{1}$ VA West Los Angeles Medical Center, West Los Angeles, CA, United States, ${ }^{2}$ David Geffen School of Medicine, University \\ of California Los Angeles, Los Angeles, CA, United States, ${ }^{3}$ Websciences International, Los Angeles, CA, United States
}

Obstructive Sleep Apnea (OSA) is a common sleep-related respiratory disorder that is associated with cognitive, cardiovascular, and metabolic morbidities. The major cause of OSA is the sleep-related reduction of upper airway muscle tone that leads to airway obstructions in individuals with anatomically narrow upper airway. This reduction is mainly due to the suppressant effect of sleep on hypoglossal motoneurons that innervate upper airway muscles. The hypoglossal motoneurons have state-dependent activity, which is decreased during the transition from wakefulness to non-rapid eye movement sleep and is further suppressed during rapid eye movement sleep. Multiple neurotransmitters and their receptors have been implicated in the control of hypoglossal motoneuron activity across the sleep-wake states. However, to date, the results of the rigorous testing show that withdrawal of noradrenergic excitation and cholinergic inhibition essentially contribute to the depression of hypoglossal motoneuron activity during sleep. The present review will focus on origins of noradrenergic and cholinergic innervation of hypoglossal motoneurons and the functional role of these neurons in the state-dependent activity of hypoglossal motoneurons.

Keywords: obstructive sleep apnea, hypoglossal motoneurons, neurotransmitters, genioglossus, upper airway

\section{NEUROTRANSMITTERS IMPLICATED IN THE CONTROL OF HYPOGLOSSAL MOTONEURONS}

Obstructive Sleep Apnea (OSA) is a sleep-related breathing disorder characterized by repetitive nocturnal apnea/hypopnea episodes due to partial or complete closure of upper airway (1-5). The resulting chronic intermittent hypoxia, hypercapnia, and frequent arousals that are accompanied by sympathetic and cardiovascular activations lead to sleep fragmentation and cognitive impairments, as well as cardiovascular and metabolic morbidities $(3,6-11)$.

In most OSA patients, the nocturnal apneic episodes result from anatomical abnormalities of upper airway aperture that are combined with the sleep-related depression of upper airway muscle tone $(3,5)$. Hypoglossal motoneurons innervate upper airway muscles including the genioglossus muscle, the main tongue protruder muscle, which plays the critical role in maintaining upper airway patency (12-17). The elevated activity of upper airway muscles, including the genioglossus muscle, keeps the airway open during wakefulness in OSA patients (18). However, their activity is reduced during non-rapid eye movement (NREM) sleep and further suppressed during rapid eye movement (REM) sleep $(2,13,16,18-23)$. Multiple neurotransmitters have been implicated in the control of state-dependent activity of hypoglossal motoneurons [reviewed by (24-27)]. 
The glycinergic nature of the inhibition of hypoglossal motoneuron activity during REM sleep was hypothesized based on the findings that strychnine, a glycine receptor antagonist, abolished large postsynaptic hyperpolarizing potentials that appeared in REM sleep during intracellular recording of hypoglossal motoneurons (28). However, the causal relationship between these potentials and the membrane hyperpolarization or the increase in rheobase, which are the main indicators of decreased neuronal excitability, has not been demonstrated. The involvement of glycinergic inhibition in REM sleep-related depression of hypoglossal motoneuron was also suggested by the increase of glycine release in the hypoglossal nucleus that has been detected using the microdialysis technique (29). In addition, an increase in concentration of another widespread inhibitory neurotransmitter in the central nervous system, gamma-Aminobutyric acid (GABA), was detected in these experiments (29). However, contrary to the effect of strychnine that abolished both membrane hyperpolarization and the rheobase increase in spinal motoneurons during REM sleepinduced atonia of postural muscles (30,31), GABA or glycinergic receptor antagonists applied on hypoglossal motoneurons did not restore the activity of hypoglossal nerve during REM sleeplike state induced by injections of carbachol, a dual cholinergic agonist, into dorsolateral pontine tegmentum in decerebrated cats (32) and anesthetized rats (33). In addition, these antagonists were not effective within the hypoglossal nucleus during natural REM sleep in freely behaving rats (34). These studies provided the evidence that either GABA or glycinergic inhibition at the level of hypoglossal motor nucleus have minimal or no effect on depression of upper airway muscles during REM sleep [reviewed by $(26,27,35,36)]$.

The disfacilitatory serotonergic mechanism has been proposed to play a key role in REM sleep-related depression of hypoglossal motoneuron activity $(32,37,38)$. This hypothesis was based on the findings that medullary serotonergic neurons project to hypoglossal motoneurons (39), serotonin has the excitatory effect on hypoglossal motoneurons (40), excitatory serotonergic 5HT2A receptors are expressed in the hypoglossal nucleus $(41,42)$; serotonergic neurons are silent during REM sleep (43) and serotonin concentration is decreased during REM sleep-like state in decerebrated cats (44) and natural REM sleep in behaving cats (45). This hypothesis was also tested by microinjections of a broad-spectrum serotonergic antagonist, methysergide, into hypoglossal motor nucleus during REM sleep-like state (46). However, despite many synergic findings supporting this hypothesis, the follow-up functional studies conducted in anesthetized and naturally sleeping rats showed that serotonin contributes minimally to REM sleep-related depression of hypoglossal motoneuron activity (47-49). In these studies, combined microinjections of methysergide and prazosin, an alpha- 1 adrenergic receptor antagonist, into the hypoglossal motor nucleus in anesthetized rats abolished REM sleep-related depression of hypoglossal motoneurons (47). However separated injections of these antagonists revealed that the inhibition of noradrenergic transmission on hypoglossal motoneurons had a major contribution to the hypoglossal depression as compared to serotonergic mechanisms (47); this contribution was estimated approximately at $90 \%$ of total effect of the antagonists (26). Comparable results were obtained in naturally sleeping rats, in which the application of terazosin, an alpha-1 adrenergic receptor antagonist, into the hypoglossal motor nucleus using the reverse microdialysis technique decreased REM sleep-related suppression of respiratory activity of genioglossus muscle by $\sim 50 \%$ (50). However, the application of serotonergic antagonists had no effect in the same preparation (48). In addition, the inhibition of serotonergic medullary raphe cells in behaving rats had minimal effects on GG activity during sleep and wakefulness (49). Furthermore, most of the brainstem noradrenergic neurons have state-dependent activity, i.e., they have highest activity during wakefulness, their firing rate is reduced in NREM sleep and it is minimal during REM sleep (51-53). Noradrenergic neurons also innervate hypoglossal motoneurons (54-56). Thus, noradrenergic system plays a critical role in suppression of hypoglossal motoneurons during REM sleep [reviewed by $(24,26,27,57)]$.

The withdrawal of glutamatergic drive has been hypothesized to contribute to REM sleep-related suppression of hypoglossal motoneurons $(29,58,59)$. In support of this hypothesis, glutamatergic neurons of intermediate reticular region (IRt) of the medulla and Kolliker-Fuse nucleus send axonal projections to the hypoglossal motoneurons $(60,61)$. In in vitro studies, the transmission of glutamate to hypoglossal motoneurons was found to be pre-synaptically inhibited by muscarinic mechanisms, which may provide the state-dependent modulation of glutamatergic release in behaving animals (62). Also, the respiratory modulation of hypoglossal motoneurons is mediated by glutamatergic neurotransmission $(58,63)$. However, the functional role of glutamatergic transmission in the state-dependent activity of genioglossus muscle did not receive adequate support in behaving rats (59).

The effect of orexin was studied using decerebrated cats and anesthetized rats $(64,65)$. In both studies orexin increased genioglossus muscle activity; this increase was abolished by combined antagonism of orexin-1 and orexin-2 receptors (65). However, it is not clear whether orexinergic transmission within the hypoglossal motor nucleus is involved in depression of hypoglossal motoneurons during NREM or REM sleep.

The application of histamine into hypoglossal motor nucleus elicits powerful activation of genioglossus muscle through histamine-1 receptors in behaving rats (66). However, antagonists of histamine-1 receptors applied into hypoglossal motor nucleus did not significantly alter spontaneous genioglossus muscle activity indicating that there is little or no endogenous histaminergic excitation of hypoglossal motoneurons (66).

Cholinergic mechanisms were found to essentially contribute to the state-dependent activity of hypoglossal motoneurons (67). The application of scopolamine, a muscarinic antagonist, into the hypoglossal nucleus in behaving rats revealed that the cholinergic inhibition plays a significant role in the regulation of state-dependent activity of the genioglossus muscle during natural sleep-wake states (67). The G-protein-coupled inwardly rectifying potassium channels that are expressed in hypoglossal motoneurons have been suggested to mediate this effect (67). 
Thus, as of today, one of the major advances in sleep and respiratory neurobiology was the discovery of powerful noradrenergic and cholinergic mechanisms that are responsible for state-dependent control of upper airway muscles (47, $50,67)$. The present review focuses on the sources of these two neurochemically distinct mechanisms and their functional role in sleep-related depression of upper airway muscles. Figure 1 shows schematically the main anatomical projections from catecholaminergic and cholinergic nuclei of the brainstem to the hypoglossal nucleus that innervates the genioglossus and other tongue muscles. The typical statedependent pattern of the spontaneous activity of the genioglossus muscle is shown in the representative polygraph recording obtained in behaving mice during sleep and wakefulness (Figure 1B).

\section{Noradrenergic Inputs to Hypoglossal Motoneurons}

The anatomical connections between the noradrenergic neurons and hypoglossal motoneurons that innervate the genioglossus muscle were first investigated by Aldes et al. (54). This study used the retrograde tracer, peroxidase-conjugated wheat germ agglutinin, which was micro-iontophoretically injected into the hypoglossal motor nucleus of the rat. The main findings of this study were that (1) noradrenergic projections to hypoglossal motoneurons originate from pontine sub-coeruleus (SubC), A7 and $\mathrm{A} 5$ noradrenergic neurons; and (2) noradrenergic neurons of locus coeruleus (LC) nucleus were not retrogradely labeled from the hypoglossal nucleus. Our studies have confirmed these findings but in addition to the SubC, A5, and A7 neurons, we also found that many catecholaminergic $\mathrm{A} 1 / \mathrm{C} 1$ neurons and scarce LC neurons send axonal projections to the hypoglossal motor nucleus $(55,56)$.

To identify if $\mathrm{A} 1 / \mathrm{Cl}$ neurons innervate genioglossus motoneurons, we injected a cre-dependent anterograde tracer (EF1a-FLEX-hChR2(H134R)-eYFP-AAV10) into the A1/C1 region in tyrosine hydroxylase (TH)-cre mice. We found that TH-positive anterogradely labeled axon terminals from the $\mathrm{A} 1 / \mathrm{C} 1$ region were mainly distributed in the ventral subdivision of hypoglossal motor nucleus (56) where genioglossus motoneurons are located $(15,68-70)$.

The activity of noradrenergic LC and SubC neurons changes across sleep-wake states; their firing rate is highest during wakefulness, reduced at the onset of NREM sleep and minimal or abolished during REM sleep (51-53). Recently, we found a significant correlation between cFos expression in noradrenergic neurons of SubC, A5, A7, and $\mathrm{A} 2 / \mathrm{C} 2$, but not $\mathrm{A} 1 / \mathrm{C} 1$, and the amount of time spent in pharmacologically induced REM sleeplike state. This suggests that, similar to LC and SubC neurons, the $\mathrm{A} 5, \mathrm{~A} 7$, and $\mathrm{A} 2 / \mathrm{C} 2$ neurons also have state-dependent activity whereas the activity of the ventrolateral medullary A1/C1 neurons is not changed with the vigilant states (53). The statedependent pattern of activity of most brainstem noradrenergic neurons projecting to hypoglossal motoneurons, prompted to hypothesize that these neurons may contribute to the REM sleep-related suppression of upper airway muscles by withdrawal of excitatory noradrenergic drive to hypoglossal motoneurons during REM sleep [reviewed by (38)].

In functional studies, the role of endogenous noradrenaline and serotonin was tested by using antagonists of noradrenergic and serotonergic receptors applied at the hypoglossal motoneuronal pool in anesthetized and behaving rats $(47,48,50)$. In support of the disfacilitation hypothesis the latter studies provided the evidence that the withdrawal of mainly noradrenergic and, to a lesser extent, serotonergic drives to upper airway motoneurons during REM sleep is the major cause of REM sleep-related depression of hypoglossal motoneurons in anesthetized rats (47). Comparable results were obtained for noradrenergic mechanisms in behaving rats (50). However, the serotonergic effects were not significant in behaving rats $[(48)$; reviewed by $(24,26,27)]$. Based on additional analysis of the antagonist effects in anesthetized rats, a neuronal network was proposed, in which the noradrenergic and serotonergic drives to hypoglossal motoneurons are mediated via additional excitatory and inhibitory interneurons, respectively (26). The main basis for the proposed network was the concept that the adrenergic and serotonergic antagonists injected into the hypoglossal nucleus diffused outside the nucleus and block corresponding receptors leading to the abolition of the hypoglossal motoneuron depression during REM sleep-like state (71). This diffusion hypothesis has received an experimental support in our preliminary studies suggesting that the noradrenergic drive to the hypoglossal nucleus is not direct (72). In addition, our recent collaborative computational study validated this network and revealed the dynamics of interaction between the monoaminergic neurons and both excitatory and inhibitory interneurons during NREM and REM sleep (73).

The important question regarding which noradrenergic neurons mostly affect hypoglossal nerve activity was studied in urethane-anesthetized rats. We tested the effect of pharmacological inhibition of noradrenergic A7, SubC, LC, and A5 groups on the level of hypoglossal nerve activity and found that the inhibition of A7 neurons significantly decreased the hypoglossal nerve activity whereas the inhibition of A5, LC, or SubC neurons did not have any effect (74-76). This data suggested that the A7 neurons provide the major NA excitatory drive to hypoglossal motoneurons among the tested noradrenergic groups (75).

The involvement of $\mathrm{A} 1 / \mathrm{Cl}$ catecholaminergic neurons in the control of the activity of hypoglossal motoneurons was recently studied using a chemogenetic technique. Since the $\mathrm{A} 1 / \mathrm{C} 1$ neurons have been suggested to have activity that is not dependent on the vigilant states (53), they could be involved in non-state-dependent control of hypoglossal motoneurons. However theoretically, there is a possibility that the release of noradrenaline from A1 terminals within the hypoglossal nucleus is modulated through some sleepspecific presynaptic inhibitory mechanisms, similar to the discovered earlier, presynaptic cholinergic control of glutamate release to hypoglossal motoneurons (62). To this end, we recently tested the role of medullary $\mathrm{A} 1 / \mathrm{C} 1$ neurons in control of the activity of genioglossus muscle using the 

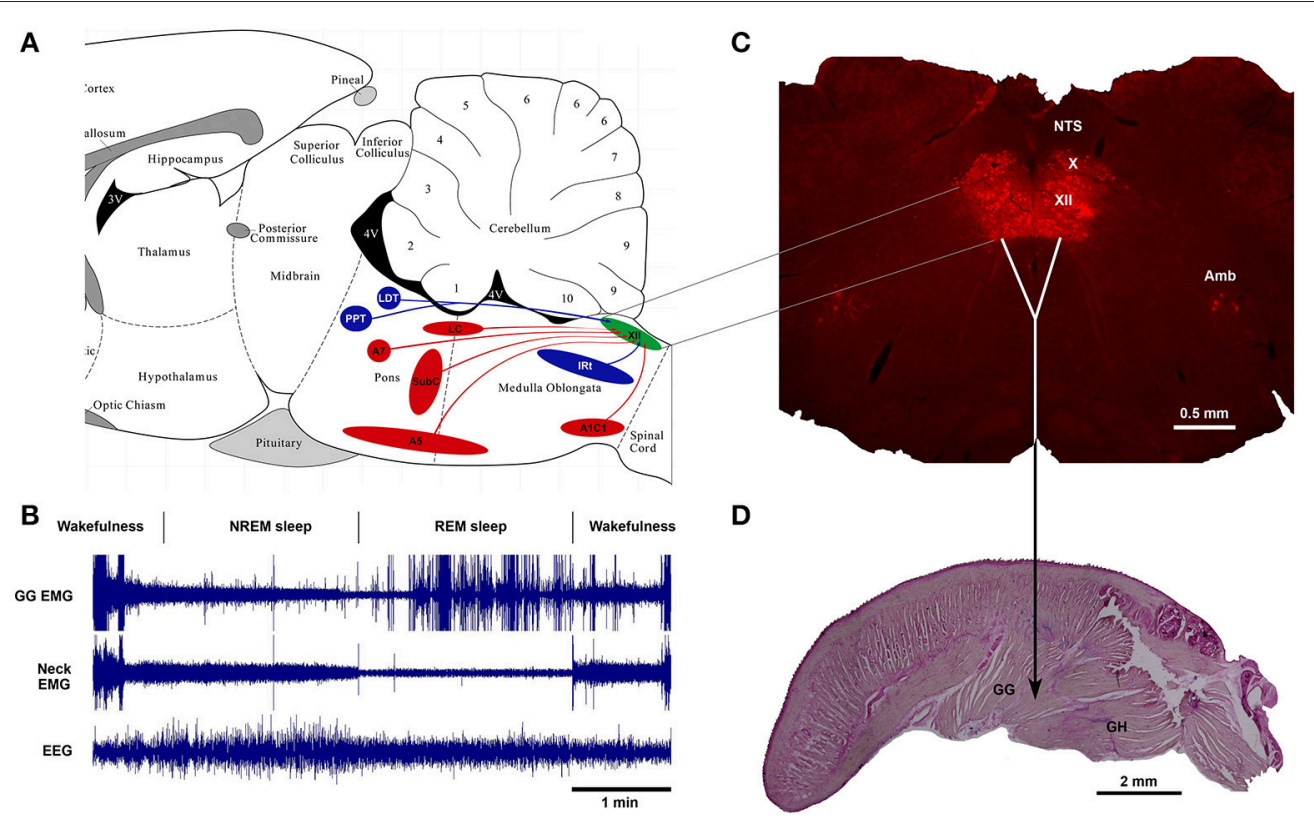

FIGURE 1 | Schematics of brainstem noradrenergic and cholinergic neurons projecting to hypoglossal motoneurons that innervate genioglossus (GG) muscle and are involved in state-dependent activity of GG muscle. (A) the location of brainstem noradrenergic neurons and cholinergic neurons that project to the hypoglossal nucleus shown on sagittal representation of a rodent brainstem. (B) An example of state-dependent activity of GG muscle during wakefulness, NREM sleep and REM sleep in a naturally sleeping mouse. The GG muscle activity is markedly decreased during transition from wakefulness to NREM sleep and further reduced during REM sleep. During later period of the REM sleep, the GG muscle generates intense twitches with gradually increasing intensity toward the end of the state. (C) A coronal medullary section of a rat brain showing the Choline Acetyltransferase-stained motoneurons in the hypoglossal motor nucleus (XII), the dorsal motor nucleus of the vagus $(X)$ and the nucleus of ambiguus (Amb). Sagittal section of a mouse tongue stained with the Neutral Red shows the geniohyoid (GH) muscle that forms the ventral floor for the genioglossus (GG) muscle, the major tongue protruder.

"designer receptor exclusively activated by a designer drug" (DREADD) technique (77). A Cre-dependent viral vector hSyn-Dio-hM4Di-mCherry-AAV10 was microinjected into the $\mathrm{A} 1 / \mathrm{C} 1$ region, which resulted in the expression of inhibitory receptors in the $\mathrm{A} 1 / \mathrm{C} 1$ neurons in behaving dopamine $\beta$ hydroxylase (DBH)-cre mice, in which the Cre-recombinase is expressed in all catecholaminergic neurons. Following the expression of $\mathrm{hM} 4 \mathrm{Di}$ in $\mathrm{A} 1 / \mathrm{C} 1$ neurons, systemic injections of the clozapine-N-Oxide (CNO) inhibited $\mathrm{A} 1 / \mathrm{Cl}$ neurons that resulted in decreased activity of genioglossus muscle. This suggested that $\mathrm{A} 1 / \mathrm{C} 1$ neurons provide a net excitatory effect on the activity of upper airway muscles. However, the relative effect of $\mathrm{CNO}$ on the genioglossus activity was similar during both wakefulness and NREM sleep suggesting that A1/C1 neurons do not contribute to depression of genioglossus activity during transition from wakefulness to NREM sleep (77).

\section{CHOLINERGIC INPUTS TO HYPOGLOSSAL MOTONEURONS}

The anatomical connections between cholinergic neurons and hypoglossal motoneurons were first investigated by Woolf and Butcher (78) using fluorescent retrograde tracers that were iontophoretically applied into the hypoglossal motor nucleus in rats. This study reported that cholinergic innervation of hypoglossal motoneurons originates from pontine laterodorsal (LDT) and pedunculopontine (PPT) tegmental nuclei. The contribution of PPT neurons to this innervation was larger than those from LDT and the projections were mainly ipsilateral (78).

In our studies, we injected retrograde tracers, FluoroGold and Cholera toxin B subunit, into the hypoglossal motor nucleus by an air pressure-driven delivery system $(79,80)$. In agreement with the earlier study of Woolf and Butcher (78), $\sim 1 \%$ of PPT/LDT cholinergic neurons projected to the hypoglossal motor nucleus. However, the PPT/LDT projections to hypoglossal motoneurons were bilateral (79). In another study, we found that $\sim 40 \%$ of cholinergic neurons of the caudal IRt region in medulla projected to the hypoglossal nucleus (80). These findings suggest that the largest cholinergic input to the hypoglossal motoneurons originates from the caudal medullary IRt region. We also found that cholinergic neurons that innervate hypoglossal motoneurons express mRNA for both muscarinic and nicotinic receptors, with the significantly high percentage of M2 muscarinic receptors present in cholinergic neurons retrogradely labeled from hypoglossal motor nucleus (80). This data suggests that the cholinergic projections from the caudal IRt region is the principal source of cholinergic drive to hypoglossal motoneurons.

Since many PPT/LDT cholinergic neurons have statedependent activity across sleep-wake states, i.e., more active 
during REM sleep or wakefulness, or both, as compared to NREM sleep (81-89), the cholinergic PPT/LDT neurons that project to the hypoglossal nucleus may contribute to pre- or postsynaptic inhibition of hypoglossal motoneurons during REM sleep. The cholinergic neurons of IRt located in caudal medullary region have also been suggested to have state-dependent activity (90). This would implicate them in the sleep-related control of hypoglossal motoneurons. However, the recording of the activity of cholinergic IRt neurons during sleep-wake states is needed to confirm their role in the mechanisms of hypoglossal motoneuron suppression during NREM sleep and/or REM sleep.

Cholinergic effects on hypoglossal motoneurons are mediated through nicotinic and muscarinic receptors $(67,91)$. The $\alpha_{3}$, $\alpha_{4}, \alpha_{7}$, and $\beta_{2}$ sub-units of nicotinic receptors (92-98) and muscarinic M1, M2, M3, M4, and M5 receptors, with the predominance of M2 receptors, are expressed in hypoglossal motoneurons (80, 99-102).

In vitro studies showed that the application of nicotinic receptor agonists excites hypoglossal motoneurons in neonatal rat (96). Also, the muscarinic receptors mediate a presynaptic cholinergic inhibition of excitatory glutamatergic transmission to hypoglossal motoneurons in vitro (62). In adult anesthetized rats, the activation of nicotinic and muscarinic receptors has respectively excitatory and inhibitory effects on the activity of genioglossus muscle (91).

The recent elegant study performed by Grace et al. (67) showed that a broad-spectrum muscarinic receptor antagonist, scopolamine, applied into the hypoglossal motor nucleus via reverse microdialysis technique significantly increased activity of genioglossus muscle during wake, NREM, and REM sleep. This study provided a strong evidence that cholinergic transmission

\section{REFERENCES}

1. White DP. Advanced Concepts in the pathophysiology of obstructive sleep apnea. Adv Otorhinolaryngol. (2017) 80:7-16. doi: 10.1159/000470522

2. Horner RL, Shea S, McIvor J, Guz A. Pharyngeal size and shape during wakefulness and sleep in patients with obstructive sleep apnoea. Q J Med. (1989) 72:719-35.

3. Jordan AS, McSharry DG, Malhotra A. Adult obstructive sleep apnoea. Lancet. (2014) 383:736-47. doi: 10.1016/S0140-6736(13)60734-5

4. Pham LV, Schwartz AR. The pathogenesis of obstructive sleep apnea. J Thorac Dis. (2015) 8:1358-72. doi: 10.3978/j.issn.2072-1439.2015.07.28

5. Sands SA, Edwards BA, Terrill PI, Taranto-Montemurro L, Azarbarzin A, Marques $M$, et al. Phenotyping pharyngeal pathophysiology using polysomnography in patients with obstructive sleep apnea. Am J Respir Crit Care Med. (2018) 197:1187-97 doi: 10.1164/rccm.201707-1435OC

6. Pack AI, Gislason T. Obstructive sleep apnea and cardiovascular disease: a perspective and future directions. Prog Cardiovasc Dis. (2009) 51:434-51. doi: 10.1016/j.pcad.2009.01.002

7. Dempsey JA, Veasey SC, Morgan BJ, O'Donnell CP. Pathophysiology of sleep apnea. Physiol Rev. (2010) 90:47-112. doi: 10.1152/physrev.00043.2008

8. Djonlagic I, Saboisky J, Carusona A, Stickgold R, Malhotra A. Increased sleep fragmentation leads to impaired offline consolidation of motor memories in humans. PLoS ONE (2012) 7:e34106. doi: 10.1371/journal.pone.0034106.

9. Li Y, Veasey SC. Neurobiology and neuropathophysiology of obstructive sleep apnea. Neuromolecular Med. (2012) 14:168-79. doi: $10.1007 /$ s12017-011-8165-7 mediated by the muscarinic receptors importantly contributes to the suppression of genioglossus muscle activity during both NREM sleep and REM sleep (67).

\section{CONCLUSION}

The significant advances have been made over last three decades in our understanding of the neurochemical mechanisms that mediate the depression of upper airway muscles during NREM sleep and further suppression in REM sleep. The powerful noradrenergic and cholinergic mechanisms with minor contribution of serotonergic drive have been shown to be responsible for state-dependent control of upper airway muscles. However, the key neural groups contributing to these mechanisms have not been yet identified. The studies summarized in the present review provides the strong anatomical and physiological foundation for future basic and translational studies, which are instrumental to obtain a comprehensive knowledge of neural circuitry underlying the OSA pathophysiology and may help to define new therapeutic targets for OSA treatment.

\section{AUTHOR CONTRIBUTIONS}

IR and VF equally contributed to writing and editing the manuscript.

\section{ACKNOWLEDGMENTS}

This study was supported by National Heart, Lung, and Blood Institute grants HL133847 and HL116845.

10. De Luca Canto G, Pachêco-Pereira C, Aydinoz S, Major PW, FloresMir C, Gozal D. Biomarkers associated with obstructive sleep apnea and morbidities: a scoping review. Sleep Med. (2015) 16:347-57. doi: 10.1016/j.sleep.2014.12.007

11. Malhotra A, Patil S, Sands S, Ayas N. Central sleep apnea in congestive heart failure. Lancet Respir Med. (2015) 3:507-8. doi: 10.1016/S2213-2600(15)00235-0

12. Lowe AA. The neural regulation of tongue movements. Prog Neurobiol. (1980) 15:295-344. doi: 10.1016/0301-0082(80)90008-8

13. Richard CA, Harper RM. Respiratory-related activity in hypoglossal neurons across sleep-waking states in cats. Brain Res. (1991) 542:167-70. doi: 10.1016/0006-8993(91)91014-R

14. Altshuler SM, Bao X, Miselis RR. Dendritic architecture of hypoglossal motoneurons projecting to extrinsic tongue musculature in the rat. J Comp Neurol. (1994) 342:538-50.

15. Dobbins EG, Feldman JL. Differential innervation of protruder and retractor muscles of the tongue in rat. J Comp Neurol. (1995) 357:376-94. doi: 10.1002/cne.903570305

16. Saboisky JP, Butler JE, McKenzie DK, Gorman RB, Trinder JA, White DP, et al. Neural drive to human genioglossus in obstructive sleep apnoea. $J$ Physiol. (2007) 585:135-46. doi: 10.1113/jphysiol.2007.139584

17. Fregosi RF, Ludlow CL. Activation of upper airway muscles during breathing and swallowing. J Appl Physiol. (2014) 116:291-301. doi: 10.1152/japplphysiol.00670.2013

18. Mezzanotte WS, Tangel DJ, White DP. Waking genioglossal electromyogram in sleep apnea patients versus normal controls 
(a neuromuscular compensatory mechanism). J Clin Invest. (1992) 89:1571-9. doi: 10.1172/JCI115751

19. Sauerland EK, Harper RM. The human tongue during sleep: electromyographic activity of the genioglossus muscle. Exp Neurol. (1976) 51:160-70.

20. Remmers JE, DeGroot WJ, Sauerland EK, Anch AM. Pathogenesis of upper airway occlusion during sleep. J Appl Physiol. (1978) 44:931-8.

21. Suratt PM, McTier RF, Wilhoit SC. Upper airway muscle activation is augmented in patients with obstructive sleep apnea compared with that in normal subjects. Am Rev Respir Dis. (1988) 137:889-94. doi: 10.1164/ajrccm/137.4.889

22. Katz ES, White DP. Genioglossus activity during sleep in normal control subjects and children with obstructive sleep apnea. Am J Respir Crit Care Med. (2004) 170:553-60. doi: 10.1164/rccm.200403-262OC

23. Eckert DJ, Malhotra A, Lo YL, White DP, Jordan AS. The influence of obstructive sleep apnea and gender on genioglossus activity during rapid eye movement sleep. Chest (2009) 135:957-64. doi: 10.1378/chest.08-2292

24. Horner RL. Neuromodulation of hypoglossal motoneurons during sleep. Respir Physiol Neurobiol. (2008) 164:179-96. doi: 10.1016/j.resp.2008.06.012

25. Horner RL, Hughes SW, Malhotra A. State-dependent and reflex drives to the upper airway: basic physiology with clinical implications. J Appl Physiol. (2014) 116:325-36. doi: 10.1152/japplphysiol.00531.2013

26. Fenik VB. Revisiting antagonist effects in hypoglossal nucleus: brainstem circuit for the state-dependent control of hypoglossal motoneurons: a hypothesis. Front Neurol. (2015) 6:254. doi: 10.3389/fneur.2015.00254

27. Kubin L. Neural control of the upper airway: respiratory and state-dependent mechanisms. Comp Physiol. (2016) 6:1801-50. doi: 10.1002/cphy.c160002

28. Yamuy J, Fung S, Xi M, Morales F, Chase M. Hypoglossal motoneurons are postsynaptically inhibited during carbachol-induced rapid eye movement sleep. Neuroscience (1999) 94:11-5. doi: 10.1016/S0306-4522(99)00355-3

29. Kodama T, Lai YY, Siegel JM. Changes in inhibitory amino acid release linked to pontine-induced atonia: An in vivo microdialysis study. J Neurosci. (2003) 23:1548-54. doi: 10.1523/JNEUROSCI.23-04-01548.2003

30. Chase M, Soja P, Morales F. Evidence that glycine mediates the postsynaptic potentials that inhibit lumbar motoneurons during the atonia of active sleep. J Neurosci. (1989) 9:743-51. doi: 10.1523/JNEUROSCI.09-03-00743.1989

31. Soja P, López-Rodríguez F, Morales F, Chase M. The postsynaptic inhibitory control of lumbar motoneurons during the atonia of active sleep: effect of strychnine on motoneuron properties. J Neurosci. (1991) 11:2804-11. doi: 10.1523/JNEUROSCI.11-09-02804.1991

32. Kubin L, Kimura H, Tojima H, Davies R, Pack A. Suppression of hypoglossal motoneurons during the carbachol-induced atonia of REM sleep is not caused by fast synaptic inhibition. Brain Res. (1993) 611:300-12. doi: 10.1016/0006-8993(93)90517-Q

33. Fenik V, Davies R, Kubin L. Combined antagonism of aminergic excitatory and amino acid inhibitory receptors in the XII nucleus abolishes REM sleeplike depression of hypoglossal motoneuronal activity. Arch Ital Biol. (2004) 142:237-49. doi: 10.4449/aib.v142i3.373

34. Morrison JL, Sood S, Liu H, Park E, Liu X, Nolan P, et al. Role of inhibitory amino acids in control of hypoglossal motor outflow to genioglossus muscle in naturally sleeping rats. J Physiol. (2003) 552:975-91. doi: 10.1113/jphysiol.2003.052357

35. Arrigoni E, Chen MC, Fuller PM. The anatomical, cellular and synaptic basis of motor atonia during rapid eye movement sleep. J Physiol. (2016) 594:5391-414. doi: 10.1113/JP271324

36. Fenik VB. Contribution of neurochemical inputs to the decrease of motoneuron excitability during non- rem and rem sleep: a systematic review. Front Neurol. (2018) 9:629. doi: 10.3389/fneur.2018.00629

37. Kubin L, Davies RO, Pack AI. Control of upper airway motoneurons during REM sleep. News Physiol Sci. (1998) 13:91-7.

38. Kubin L, Davies RO. Mechanisms of airway hypotonia. In: Pack AI editor. Sleep Apnea Pathogenesis, Diagnosis, and Treatment Dekker. New York, NY: Dekker (2002). p. 99-154.

39. Manaker S, Tischler LJ. Origin of serotonergic afferents to the hypoglossal nucleus in the rat. J Comp Neurol. (1993) 334:466-76.

40. Kubin L, Tojima H, Davies RO, Pack AI. Serotonergic excitatory drive to hypoglossal motoneurons in the decerebrate cat. Neurosci Lett. (1992) 139:243-8. doi: 10.1016/0304-3940(92)90563-M
41. Okabe S, Mackiewicz M, Kubin L. Serotonin receptor mRNA expression in the hypoglossal motor nucleus. Respir Physiol. (1997) 110, 151-60. doi: 10.1016/S0034-5687(97)00080-7

42. Fay R, Kubin L. Pontomedullary distribution of 5-HT2A receptorlike protein in the rat. J Comp Neurol. (2000) 418:323-45. doi: 10.1002/(SICI)1096-9861(20000313)418:3<323::AID-CNE7>3.0.CO;2-Y

43. Jacobs BL, Azmitia EC. Structure and function of the brain serotonin system. Physiol Rev. (1992) 72:165-229. doi: 10.1152/physrev.1992.72.1.165

44. Kubin L, Reignier C, Tojima H, Taguchi O, Pack AI, Davies RO. Changes in serotonin level in the hypoglossal nucleus region during carbacholinduced atonia. Brain Res. (1994) 645:291-302. doi: 10.1016/0006-8993(94) 91663-2

45. Lai YY, Kodama T, Siegel JM. Changes in monoamine release in the ventral horn and hypoglossal nucleus linked to pontine inhibition of muscle tone: an in vivo microdialysis study. J Neurosci. (2001) 21:7384-91. doi: 10.1523/JNEUROSCI.21-18-07384.2001

46. Kubin L, Tojima H, Reignier C, Pack AI, Davies RO. Interaction of serotonergic excitatory drive to hypoglossal motoneurons with carbachol-induced, REM sleep-like atonia. Sleep. (1996) 19:187-95. doi: $10.1093 /$ sleep/19.3.187

47. Fenik V, Davies R, Kubin L. REM sleep-like atonia of hypoglossal (XII) motoneurons is caused by loss of noradrenergic and serotonergic inputs. Am J Respir Crit Care Med. (2005) 172:1322-30. doi: 10.1164/rccm.200412-1750OC

48. Sood S, Morrison JL, Liu H, Horner RL. Role of endogenous serotonin in modulating genioglossus muscle activity in awake and sleeping rats. Am J Respir Crit Care Med. (2005) 172:1338-47. doi: 10.1164/rccm.200502-258OC

49. Sood S, Raddatz E, Liu X, Liu H, Horner RL. Inhibition of serotonergic medullary raphe obscurus neurons suppresses genioglossus and diaphragm activities in anesthetized but not conscious rats. J Appl Physiol. (2006) 100:1807-21. doi: 10.1152/japplphysiol.01508.2005

50. Chan E, Steenland H, Liu H, Horner R. Endogenous excitatory drive modulating respiratory muscle activity across sleep-wake states. Am J Respir Crit Care Med. (2006) 174:1264-73. doi: 10.1164/rccm.200605-597OC

51. Aston-Jones G, Bloom FE. Activity of norepinephrine-containing locus coeruleus neurons in behaving rats anticipates fluctuations in the sleep-waking cycle. J Neurosci. (1981) 1:876-86. doi: 10.1523/JNEUROSCI.01-08-00876.1981

52. Reiner PB. Correlational analysis of central noradrenergic neuronal activity and sympathetic tone in behaving cats. Brain Res. (1986) 378:86-96. doi: 10.1016/0006-8993(86)90288-X

53. Rukhadze I, Fenik V, Branconi J, Kubin L. Fos expression in pontomedullary catecholaminergic cells following rapid eye movement sleep-like episodes elicited by pontine carbachol in urethane-anesthetized rats. Neurosci. (2008) 152:208-22. doi: 10.1016/j.neuroscience.2007.11.013

54. Aldes L, Chapman M, Chronister R, Haycock J. Sources of noradrenergic afferents to the hypoglossal nucleus in the rat. Brain Res Bull. (1992) 29:93142. doi: 10.1016/0361-9230(92)90168-W

55. Rukhadze I, Kubin L. Differential pontomedullary catecholaminergic projections to hypoglossal motor nucleus and viscerosensory nucleus of the solitary tract. J Chem Neuroanat. (2007) 33:23-33. doi: 10.1016/j.jchemneu.2006.10.001

56. Rukhadze I, Fuller PM. Medullary A1/C1 catecholaminergic neurons directly innervate hypoglossal motoneurons. Sleep (2015) 38(Suppl.):A55.

57. kubin L. Sleep-wake control of the upper airway by noradrenergic neurons, with and without hypoxia. Prog. Brain Res. (2014) 209:255-74. doi: 10.1016/B978-0-444-63274-6.00013-8.

58. Steenland HW, Liu H, Sood S, Liu X, Horner RL. Respiratory activation of the genioglossus muscle involves both non-NMDA and NMDA glutamate receptors at the hypoglossal motor nucleus in vivo. Neuroscience (2006) 138:1407-24. doi: 10.1016/j.neuroscience.2005.12.040

59. Steenland HW, Liu H, Horner RL. Endogenous glutamatergic control of rhythmically active mammalian respiratory motoneurons in vivo. J Neurosci. (2008) 28:6826-35. doi: 10.1523/JNEUROSCI.1019-08.2008

60. Travers JB, Yoo JE, Chandran R, Herman K, Travers SP. Neurotransmitter phenotypes of intermediate zone reticular formation projections to the motor trigeminal and hypoglossal nuclei in the rat. J Comp Neurol. (2005) 488:28-47. doi: 10.1002/cne.20604 
61. Yokota S, Niu JG, Tsumori T, Oka T, Yasui Y. Glutamatergic Kolliker-Fuse nucleus neurons innervate hypoglossal motoneurons whose axons form the medial (protruder) branch of the hypoglossal nerve in the rat. Brain Res. (2011) 1404:10-20. doi: 10.1016/j.brainres.2011.06.025

62. Bellingham MC, Berger AJ. Presynaptic depression of excitatory synaptic inputs to rat hypoglossal motoneurons by muscarinic M2 receptors. $J$ Neurophysiol. (1996) 76:3758-70.

63. Funk GD, Smith JC, Feldman JL. Generation and transmission of respiratory oscillations in medullary slices: role of excitatory amino acids. J Neurophysiol. (1993) 70:1497-515.

64. Peever JH, Lai YY, Siegel JM. Excitatory effects of hypocretin-1 (orexinA) in the trigeminal motor nucleus are reversed by NMDA antagonism. $J$ Neurophysiol. (2003) 89:2591-2600. doi: 10.1152/jn.00968.2002

65. Zhang GH, Liu ZL, Zhang BJ, Geng WY, Song NN, Zhou W, et al. OrexinA activates hypoglossal motoneurons and enhances genioglossus muscle activity in rats. Br J Pharmacol. (2014) 171:4233-46. doi: 10.1111/bph.12784

66. Bastedo T, Chan E, Park E, Liu H, Horner RL. Modulation of genioglossus muscle activity across sleep-wake states by histamine at the hypoglossal motor pool. Sleep. (2009) 32:1313-24. doi: 10.1093/sleep/32.10.1313

67. Grace KP, Hughes SW, Horner RL. Identification of the mechanism mediating genioglossus reactivation muscle suppression in REM sleep. Am J Respir Crit Care Med. (2013) 187:311-9. doi: 10.1164/rccm.201209-1654OC

68. Rukhadze I, Fenik VB, Benincasa KE, Price A, Kubin L. Chronic intermittent hypoxia alters density of aminergic terminals and receptors in the hypoglossal motor nucleus. Am J Respir Crit Care Med. (2010) 182:1321-9. doi: 10.1164/rccm.200912-1884OC

69. Aldes LD. Subcompartmental organization of the ventral (protrusor) compartment in the hypoglossal nucleus of the rat. J Comp Neurol. (1995) 353:89-108. doi: 10.1002/cne.903530109

70. Aldes LD. The enkephalinergic innervation of the genioglossus musculature in the rat: implications for the respiratory control of the tongue. Brain Res. (1998) 780:67-73. doi: 10.1016/S0006-8993(97)01126-8

71. Fenik V, Davies R, Kubin L. Noradrenergic, serotonergic and GABAergic antagonists injected together into the XII nucleus abolish the REM sleeplike depression of hypoglossal motoneuronal activity. J Sleep Res. (2005) 14:419-29. doi: 10.1111/j.1365-2869.2005.00461.x

72. Fenik VB, Rukhadze I. Control of hypoglossal motoneuron excitability by noradrenergic neurons is not direct. Sleep (2016) 39(Suppl):A47.

73. Naji M, Komarov M, Krishnan GP, Malhotra A, Powell FL, Rukhadze I., et al. Computational model of brainstem circuit for state-dependent control of hypoglossal motoneurons. J Neurophysiol. (2018) 120:296-305. doi: 10.1152/jn.00728.2017

74. Fenik V, Marchenko V, Janssen P, Davies RO, Kubin L. A5 cells are silenced when REM sleep-like signs are elicited by pontine carbachol. J Appl Physiol. (2002) 93:1448-56. doi: 10.1152/japplphysiol.00225.2002

75. Fenik VB, Rukhadze I, Kubin L. Inhibition of pontine noradrenergic A7 cells reduces hypoglossal nerve activity in rats. Neurosci. (2008) 157:473-82. doi: 10.1016/j.neuroscience.2008.08.069

76. Fenik VB, Marchenko V, Davies RO, Kubin L. Inhibition of A5 neurons facilitates the occurrence of rem sleep-like episodes in urethane-anesthetized rats: a new role for noradrenergic A5 neurons? Front Neurol. (2012) 3:119. doi: 10.3389/fneur.2012.00119

77. Rukhadze I, Carballo NJ, Bandaru SS, Malhotra A, Fuller PM, Fenik VB. Catecholaminergic A1/C1 neurons contribute to the maintenance of upper airway muscle tone but may not participate in NREM sleeprelated depression of these muscles. Resp Physiol Neurobiol. (2017) 244:41-50. doi: 10.1016/j.resp.2017.07.001

78. Woolf NJ, Butcher LL. Cholinergic systems in the rat brain: IV. descending projections of the pontomesen- cephalic tegmentum. Brain Res Bull. (1989) 23:519-40.

79. Rukhadze I, Kubin L. Mesopontine cholinergic projections to the hypoglossal motor nucleus. Neurosci Lett. (2007) 413:121-5. doi: 10.1016/j.neulet.2006.11.059

80. Volgin DV, Rukhadze I, Kubin L. Hypoglossal premotor neurons of the intermediate medullary reticular region express cholinergic markers. J Appl Physiol. (2008) 105:1576-84. doi: 10.1152/japplphysiol.90670.2008

81. Sakai K. Discharge properties of presumed cholinergic and noncholinergic laterodorsal tegmental neurons related to cortical activation in non-anesthetized mice. Neuroscience. (2012) 224:172-90. doi: 10.1016/j.neuroscience.2012.08.032

82. Boucetta S, Cisse' Y, Mainville L, Morales M, Jones BE. Discharge profiles across the sleep-waking cycle of identified cholinergic, GABAergic, and glutamatergic neurons in the pontomesencephalic tegmentum of the rat. $J$ Neurosci. (2014) 34:4708-727. doi: 10.1523/JNEUROSCI.2617-13.2014

83. Maloney KJ, Mainville L, Jones BE. Differential c-Fos expression in cholinergic, monoaminergic, and GABAergic cell groups of the pontomesencephalic tegmentum after paradoxical sleep deprivation and recovery. $J$ Neurosci. (1999) 19:3057-72. doi: 10.1523/JNEUROSCI.19-08-03057.1999

84. el Mansari M, Sakai K, Jouvet M. Unitary characteristics of presumptive cholinergic tegmental neurons during the sleep-waking cycle in freely moving cats. Exp Brain Res. (1989) 76:519-29. doi: 10.1007/BF00248908

85. Steriade M, Datta S, Pare' D, Oakson G, Curro' Dossi RC. Neuronal activities in brain-stem cholinergic nuclei related to tonic activation processes in thalamocortical systems. J Neurosci. (1990) 10:2541-59. doi: 10.1523/JNEUROSCI.10-08-02541.1990

86. Kayama Y, Ohta M, Jodo E. Firing of 'possibly' cholinergic neurons in the rat laterodorsal tegmental nucleus during sleep and wakefulness. Brain Res. (1992) 569:210-20.

87. Shiromani PJ, Winston S, McCarley RW. Pontine cholinergic neurons show Fos-like immunoreactivity asso- ciated with cholinergically induced REM sleep. Mol Brain Res. (1996) 38:77-84. doi: 10.1016/0169-328X(95)00325-M

88. Van Dort CJ, Zachs DP, Kenny JD, Zheng S, Goldblum RR, Gelwan NA, et al. Optogenetic activation of cholinergic neurons in the PPT or LDT induces REM sleep. Proc Natl Acad Sci USA. (2015) 112:584-9. doi: $10.1073 /$ pnas.1423136112

89. Kroeger D, Ferrari LL, Petit G, Mahoney CE, Fuller PM, Arrigoni E, et al. Cholinergic, glutamatergic, and gabaergic neurons of the pedunculopontine tegmental nucleus have distinct effects on sleep/wake behavior in mice. $J$ Neurosci. (2017) 37:1352-66. doi: 10.1523/JNEUROSCI.1405-16.2016

90. Holmes CJ, Jones BE. Importance of cholinergic, GABAergic, serotonergic and other neurons in the medial medullary reticular formation for sleepwake states studied by cytotoxic lesions in the cat. Neuroscience (1994) 62:1179-200.

91. Liu X, Sood S, Liu H, Horner RL. Opposing muscarinic and nicotinic modulation of hypoglossal motor output to genioglossus muscle in rats in vivo. J Physiol (2005) 565:965-80. doi: 10.1113/jphysiol.2005.084657

92. Wada E, Wada K, Boulter J, Deneris E, Heinemann S, Patrick J, et al. Distribution of alpha 2, alpha 3, alpha 4, and beta 2 neuronal nicotinic receptor subunit mRNAs in the central nervous system: a hybridi zation histochemical study in the rat. J Comp Neurol. (1989) 284:314-35. doi: $10.1002 / \mathrm{cne} .902840212$

93. Zaninetti M, Tribollet E, Bertrand D, Raggenbass M. Presence of functional neuronal nicotinic acetylcholine receptors in brainstem motoneurons of the rat. Eur J Neurosci. (1999) 11:2737-48.

94. Dehkordi O, Millis RM, Dennis GC, Coleman BR, Johnson SM, Changizi $\mathrm{L}$, et al. Alpha-7 and alpha-4 nicotinic receptor subunit immunoreactivity in genioglossus muscle motoneurons. Respir Physiol Neurobiol. (2005) 145:15361. doi: 10.1016/j.resp.2004.09.003

95. Robinson DM, Peebles KC, Kwok H, Adams BM, Clarke LL, Woollard GA, et al. Prenatal nicotine exposure increases apnoea and reduces nicotinic potentiation of hypoglossal inspiratory output in mice. J Physiol. (2002) 538:957-73. doi: 10.1113/jphysiol.2001.012705

96. Chamberlin NL, Bocchiaro CM, Greene RW, Feldman JL. Nicotinic excitation of rat hypoglossal motoneu rons. Neuroscience. (2002) 115:861-70. doi: 10.1016/S0306-4522(02)00454-2

97. Shao XM, Feldman JL. Cholinergic neurotransmission in the preBötzinger complex modulates excitability of inspiratory neurons and regulates respiratory rhythm. Neuroscience (2005) 130:1069-81. doi: 10.1016/j.neuroscience.2004.10.028

98. Shao XM, Tan W, Xiu J, Puskar N, Fonck C, Lester HA, et al. Alpha4* nicotinic receptors in preBotzinger complex mediate cholinergic/nicotinic modulation of respiratory rhythm. J Neurosci. (2008) 28:519-28. doi: 10.1523/JNEUROSCI.3666-07.2008

99. Wamsley JK, Lewis MS, Young WS III, Kuhar MJ. Autoradiographic localization of muscarinic cholinergic receptors in rat brainstem. 
J Neurosci. (1981) 1:176-191. doi: 10.1523/JNEUROSCI.01-02-001 76.1981

100. Mallios VJ, Lydic R, Baghdoyan HA. Muscarinic receptor subtypes are differentially distributed across brain stem respiratory nuclei. Am J Physiol. (1995) 268:L941-L949.

101. Bellingham MC, Ireland MF. Contribution of cholinergic systems to statedependent modulation of respiratory control. Respir Physiol Neurobiol. (2002) 131:135-44. doi: 10.1016/S1569-9048(02)00043-5

102. Hellström J, Oliveira AL, Meister B, Cullheim S. Large cholinergic nerve terminals on subsets of motoneurons and their relation to muscarinic receptor type 2. J Comp Neurol. (2003) 460:476-86. doi: 10.1002/cne.10648
Conflict of Interest Statement: The authors declare that the research was conducted in the absence of any commercial or financial relationships that could be construed as a potential conflict of interest.

Copyright (c) 2018 Rukhadze and Fenik. This is an open-access article distributed under the terms of the Creative Commons Attribution License (CC BY). The use, distribution or reproduction in other forums is permitted, provided the original author(s) and the copyright owner(s) are credited and that the original publication in this journal is cited, in accordance with accepted academic practice. No use, distribution or reproduction is permitted which does not comply with these terms. 